\title{
Geological Hazards in Samtskhe-Javakheti Region (Georgia)
}

\author{
Gaprindashvili George1,2, Gerkeuli Tamaz', Tsereteli Emil1,2, Gaprindashvili Merab1 \\ ${ }^{1}$ Department of Geology, National Environmental Agency, Ministry of Environment and Natural Resources \\ Protection, Tbilisi, Georgia \\ ${ }^{2}$ Vakhushti Bagrationi Institute of Geography, Ivane Javakhishvili Tbilisi State University, Tbilisi, Georgia \\ Email: gaprindashvili.george@gmail.com, george.gaprindashvili@tsu.ge
}

Received 17 February 2016; accepted 19 March 2016; published 22 March 2016

Copyright (C) 2016 by authors and Scientific Research Publishing Inc.

This work is licensed under the Creative Commons Attribution International License (CC BY). http://creativecommons.org/licenses/by/4.0/

(c) (i) Open Access

\begin{abstract}
Hundreds of settlements, agricultural lands, roads, oil and gas pipelines' routes, towers of high voltage transmission lines, hydro-technical-meliorative objects, mountain resorts, etc. are periodically experiencing strong influence of landslide-gravitational and debris flow/mudflow processes (often with catastrophic results). Almost all landscape-geographic zones-from Black Sea coastal region, to mountainous-nival, where geo-ecological situation is severely complicated, are located in dangerous area of disaster. Negative social-economic, demographic and ecological consequences caused by debris flow/mudflows and landslide-gravitational processes, are seen in all spheres of human activity. In mountainous regions there is especially complicated situation, where in conditions of extreme activation of disaster, in many cases population displacement and transfer to other regions is needed. Because of it, in second half of 20th century, tens of villages in mountainous regions were desolated and agricultural lands were abandoned. Most alarming scenario is that such events are accompanied by loss of human lives. Only after 1995 up until now geological and geo-morphological processes in Georgia caused loss of lives of more than 139 persons. Even in conditions of routine activation of disaster, total economical damages reach tens of millions of dollars, and in case of extreme development-hundreds of millions.
\end{abstract}

\section{Keywords}

Geomorphology, Geology, Landslide, Debris Flow, Georgia

\section{Introduction}

Management and prognosis of natural processes occurring in environment is a main objective for modern civilization. Research of landslide, debris flow/mudflow, rockfall, flood, flashflood and other exodynamic processes 
became especially actual from the second half of 20th century when it became obvious that measures planned for protection of population and engineering and economical facilities from natural disasters proved insufficient, for the solution of most important social-economic, demographic, ecological and political problems.

The region of Samtskhe-Javakheti, with its geographic location, geo-morphological and geological complexity, landscape-climatic diverse spectrum and potential of sustained development of country, is a unique region. This is determined by natural and historical factors although due to the historical and political conditions this region was one of the undeveloped agrarian regions in the country until XXI century. Through the region transit communications of international importance are passing such as Baku-Tbilisi-Ceyhan oil pipeline and South Caucasus gas pipeline, also highways connecting Georgia with Turkey and Armenia. Baku-Tbilisi-Kars railway is currently under construction.

The article represents a research carried out for the purpose of investigation and estimation of territories damaged by natural disasters in Samtskhe-Javakheti region.

Despite optimal natural and landscape conditions in the region, its social-economic development and demographic situation are significantly hindered and complicated by the large-scale reactivation and development of natural disasters where all kind of natural disaster events are occurred characteristic for mountainous regionslandslides, mudflows, floods, erosion of river banks, etc. At the same time, all territory of the region is located in the hazard zone of 8 - 9 magnitude quakes. Therefore, it is important to study processes developing on this territory, determine risk of danger and elaborate prognosis.

\section{Study Area}

The region consists of 6 municipalities (Borjomi, Akhaltsikhe, Aspindza, Adigeni, Akhalkalaki, Ninotsminda), its total area is $6412.9 \mathrm{~km}^{2}$. There are 270 settlements in the region, and population, according to 2002 census, is 207698 . Average density is 32.37 persons per $\mathrm{km}^{2}$ (Figure 1).

Formation of Samtskhe-Javakheti region started at the end of Oligocene when, as a result of neo-tectonic movements and volcanic events plateau areas of Lesser Caucasus and southern Georgia were created which, in their turn, are divided on several districts and sub-regions, according to their genesis [1] [2].

Yields of Late Cretaceous rocks oldest in the region are fixed in the vicinity of villages Nakalakevi and Tmogvi. Paleocene and Early Eocene sediments are represented in BorjomiFlyschfacies, and sediments of

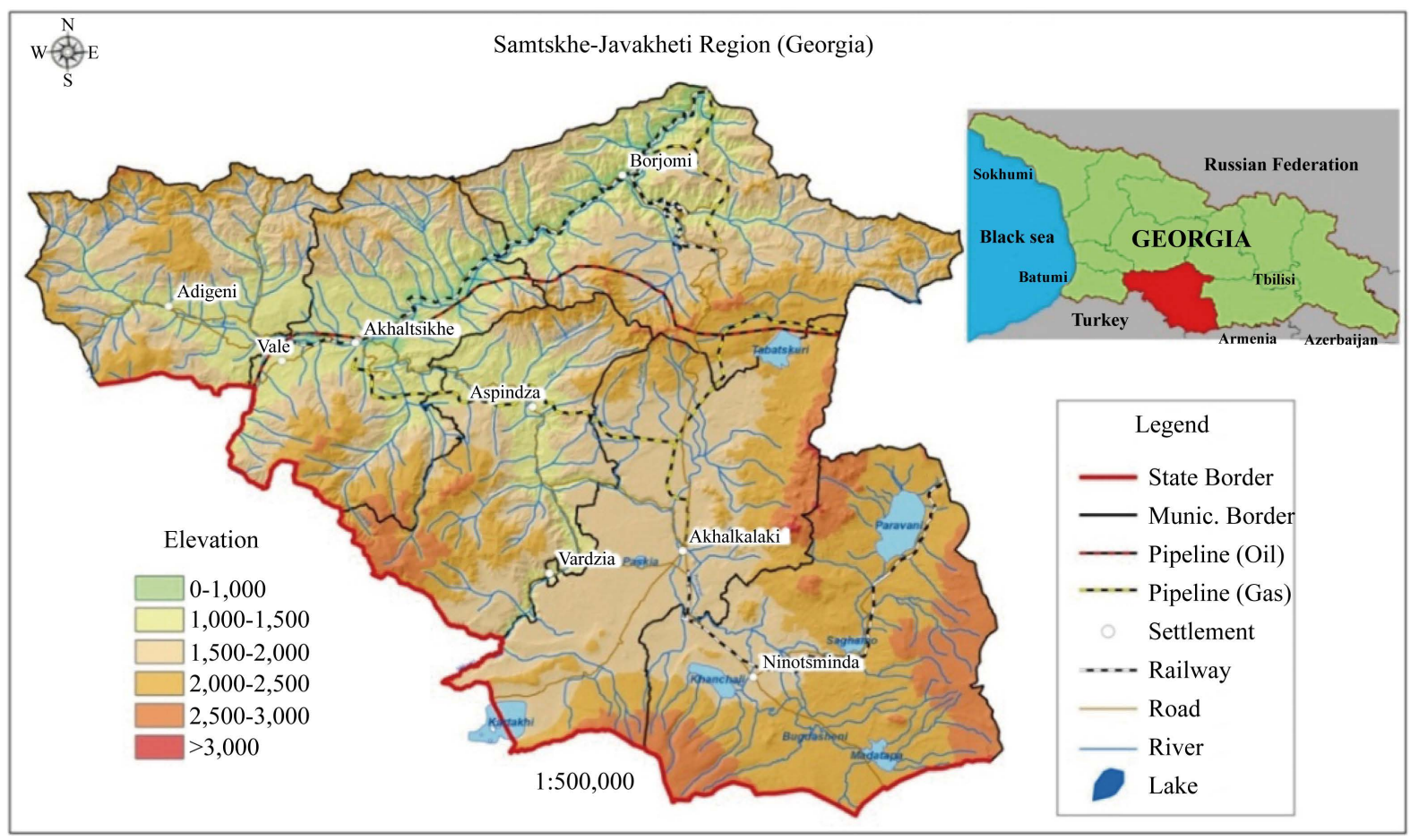

Figure 1. Study area. 
Middle and Late Eocene can be found on the territories of Aspindza, Adigeni and Akhaltsikhe municipalities. Oligocene sediments are mostly prevalent in Adigeni and Akhaltsikhe municipalities [3] [4].

Early Pliocene-Early Quaternary sediments are known under the name of Tsalka-Akhalkalaki horizon. Quaternary sediments are widely spread in the boundaries of this region. Most common are diluvium-eluvial and proluvial depositions. Alluvial sediments are left in river valleys and terraces. Colluvial sediments are also widespread, its thickness often reaches $20 \mathrm{~m}$. Intrusive rocks are not common in the region and are represented by diorites, gabbro diorites, diabases and subvolcanic bodies. The region is distinguished by occurrences of modern engineering-geological processes which in some degree are damaging economy. Activation of processes is stimulated by neotectonic movements and seismic events. Also, economic activity is playing significant role.

\section{Modern Geodynamic Processes in Southern Mountainous Region of Georgia}

Exogenous processes such as landslides, mudflows, erosion, rockfalls, floods, avalanches, weathering, marsh formation are widespread. Their types, intensity and formation-activation are defined by seismic, tectonic, geological-geomorphologic, meteorological, hydrogeological and anthropogenic factors. Geodynamic stresses of territory under research is increased by the fact that mountainous region of Georgia is completely located in the risk zone of 8 - 9 magnitude earthquake which, in most cases, along with other factors, significantly increases formation and activation of exogenous processes. From the anthropogenic factors especially negative influence on the complication of geological situation have uncontrolled and intense wood-felling, overload of slopes by heavy buildings, faults of water supply systems of local settlements, unsystematic and excessive watering, negligence of elementary engineering-geological requirements during construction of engineering objects and low conscience of population in relation to the exogenous processes. By today on the territory being studied up to 200 landslide sites are fixed. There are known up to 50 sites of river banks erosion of various scales, floods and water-loggings are mainly occurred in the valley of river Mtkvari. Marsh formation is observed on the sites adjacent to the lakes of Javakheti mountainous region. Also in Javakheti there are widespread erosions, solifluctional processes (“cryogenic landslides”), floods and water-loggings, areal erosion, rockfalls and avalanches. More than 100 settlements on the territory under research are in various scale hazard situation of exogenous processes (Figure 2).

Landscape peculiarity of the region is determined by specific, relief (Figure 3), geological and different climatic conditions. The region is located in the risk zone of 8 - 9 magnitude earthquakes. Activation of landslide processes is tightly connected, along with other factors, to the amount of atmospheric precipitation and its seasonal distribution. Precipitation is one of, and, in most cases, most provoking factor in genesis and activation of landslide processes. Bellow it is presented number of settlements per municipality damaged by different type of hazards (Table 1, Figure 4, Figure 5).

\section{Borjomi Municipality}

Borjomi city - still under the danger of rockfall are residential buildings which located at the foot of almost vertical cliff with height of 50 - $60 \mathrm{~m}$, situated on the left bank of river Mtkvari (Figure 6). The exposition of cliff is southern-eastern, geologically it is represented by Paleogene-Early Eocene (BorjomiFlysch) marls, sandstones and tuffs. As a result of physical erosion of rocks, fall of materials with various sizes and also separate clods is taking place. 3 years ago, on the same street, 20-tonne clod felt and damaged residential building. In 50s of previous century, at the slope foot, for the purpose of population protecting, $200-220 \mathrm{~m}$ long trench was dug, in which crumbled materials were accumulated. This trench now is filled and lost its function. For the purpose of prevention it is necessary to clear the trench and periodically clear the slope.

In the Orbeliani street sustaining walls of 12-13-10 and $15 \mathrm{~m}$ long, ruined and damaged in 2013, were restored. Sustaining wall of $25 \mathrm{~m}$ long, located on the right bank of river Mtkvari, should be restored (Figure 7).

Village Dgvari-in this village landslide of modern generation is active. Its area is up to 300 ha. The landslide is plastic, creeping type. Its length is $2.0 \mathrm{~km}$, width $-1.5 \mathrm{~km}$, thickness-15 - $20 \mathrm{~m}$. In this village all buildings are damaged (Figure 8, Figure 9).

Village Tadzrisi-landslide developed at the top of the village is in stable phase. Its area is up to 48 ha. It is plastic, creeping type. Length is $0.5-0.6 \mathrm{~km}$, width-0.7 - $0.8 \mathrm{~km}$, thickness—up to $3 \mathrm{~m}$. In case of activation the landslide will endanger local population and Baku-Ceyhan oil pipeline. For the purpose of prevention pipeline constructors performed anti-landslide works of high quality. 


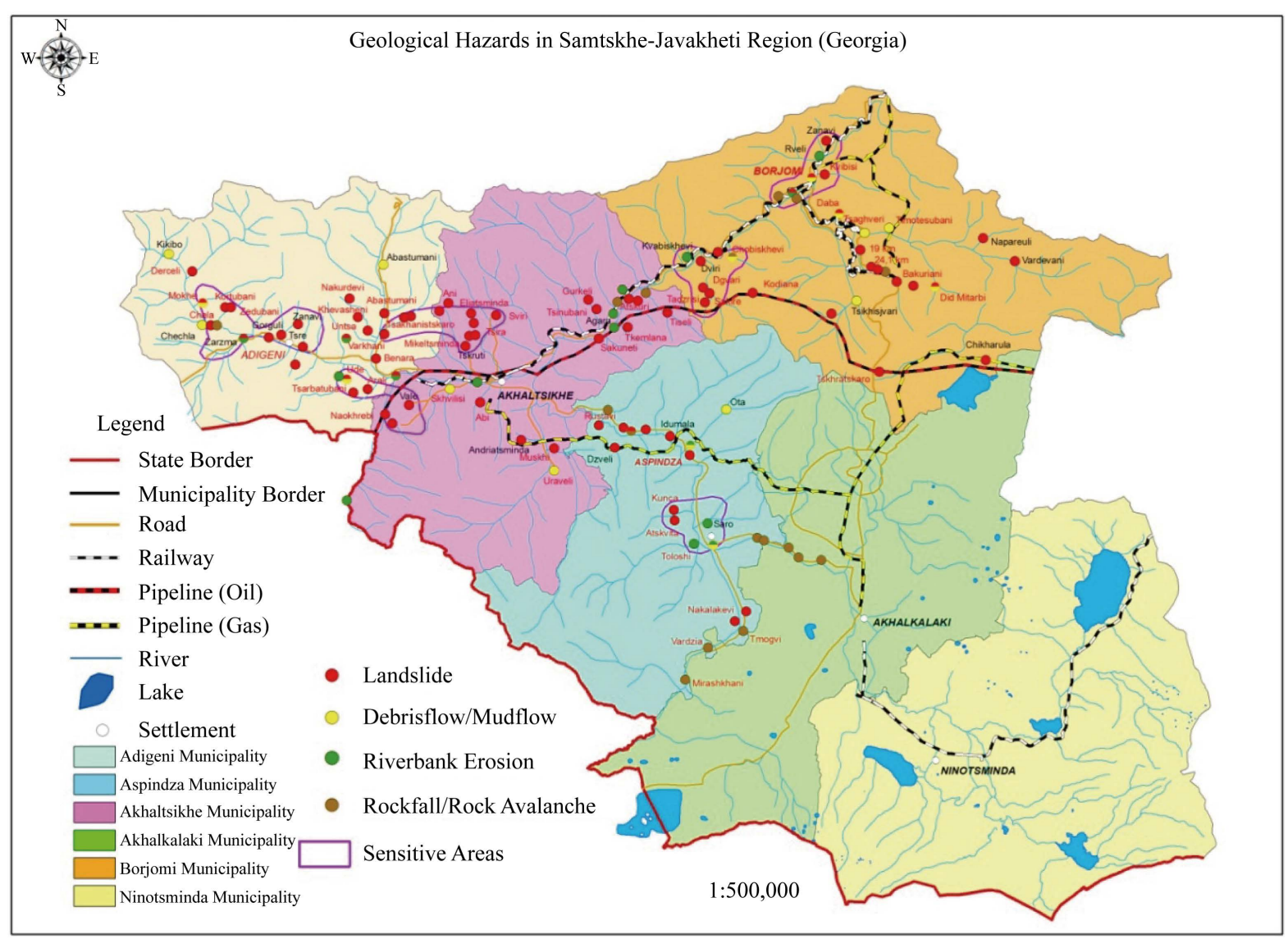

Figure 2. Geological Hazard map in Samtskhe-Javakheti region.

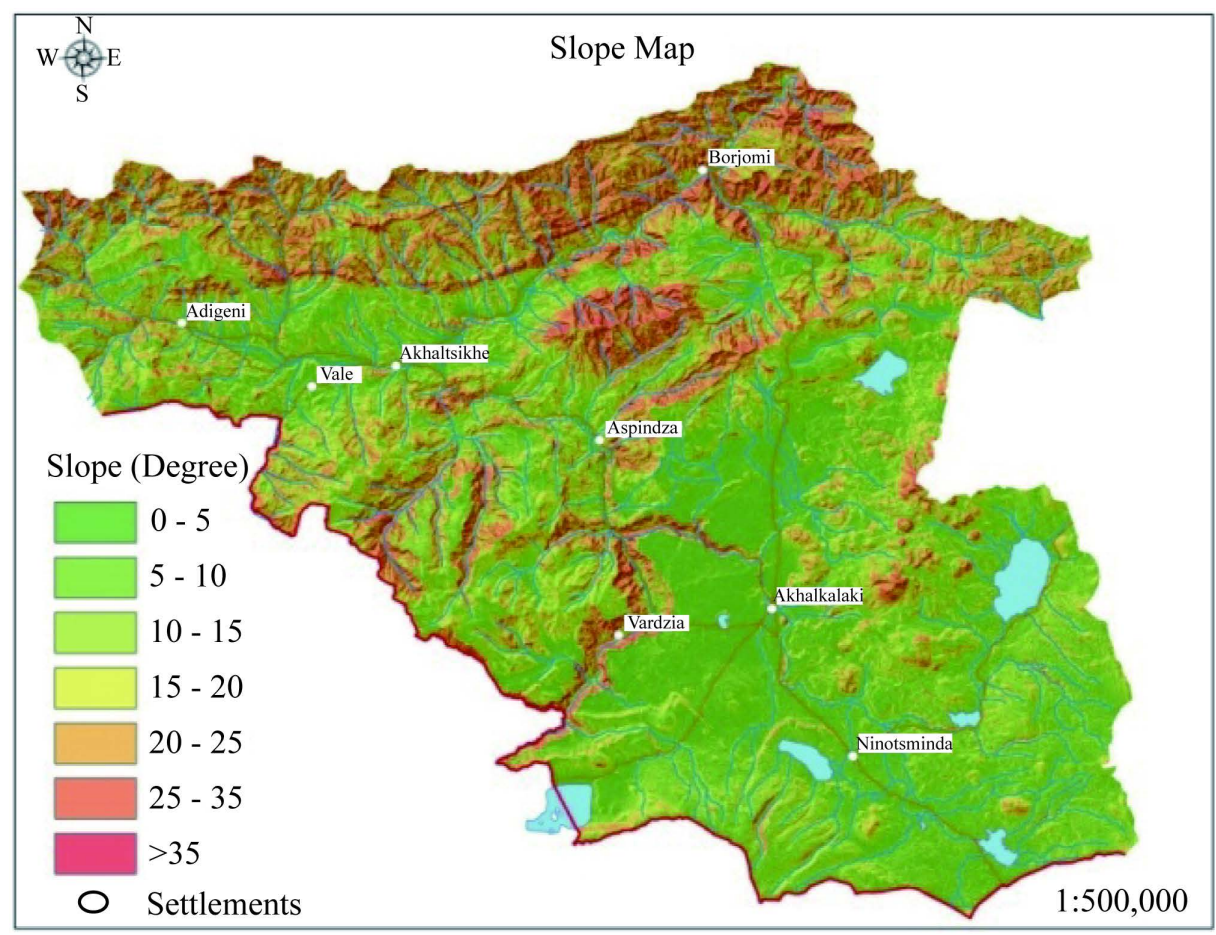

Figure 3. Slope map of Samtskhe-Javakheti region. 
Table 1. Number of settlements in municipality damaged by Disaster Geological Processes.

\begin{tabular}{|c|c|c|c|c|c|c|c|}
\hline \multirow{2}{*}{$\#$} & \multirow{2}{*}{ Municipality } & \multirow{2}{*}{$\begin{array}{l}\text { Number of } \\
\text { settlements }\end{array}$} & \multirow{2}{*}{$\begin{array}{l}\text { Number of settlements under } \\
\text { Geological Hazard risk }\end{array}$} & \multicolumn{3}{|c|}{ Damage level (hazard category) } & \multirow{2}{*}{$\begin{array}{l}\text { Number of settlemen } \\
\text { without hazard }\end{array}$} \\
\hline & & & & High & Moderate & Low & \\
\hline 1 & Adigeni & 57 & 26 & 2 & 7 & 17 & 31 \\
\hline 2 & Akhaltsikhe & 49 & 32 & 2 & 11 & 19 & 17 \\
\hline 3 & Aspindza & 24 & 21 & 6 & 7 & 8 & 3 \\
\hline 4 & Borjomi & 43 & 24 & 4 & 13 & 7 & 19 \\
\hline 5 & akhalkalaki & 65 & - & - & - & - & 65 \\
\hline \multirow[t]{2}{*}{6} & Ninotsminda & 32 & - & - & - & - & 32 \\
\hline & Total & 270 & 103 & 14 & 38 & 51 & 167 \\
\hline
\end{tabular}

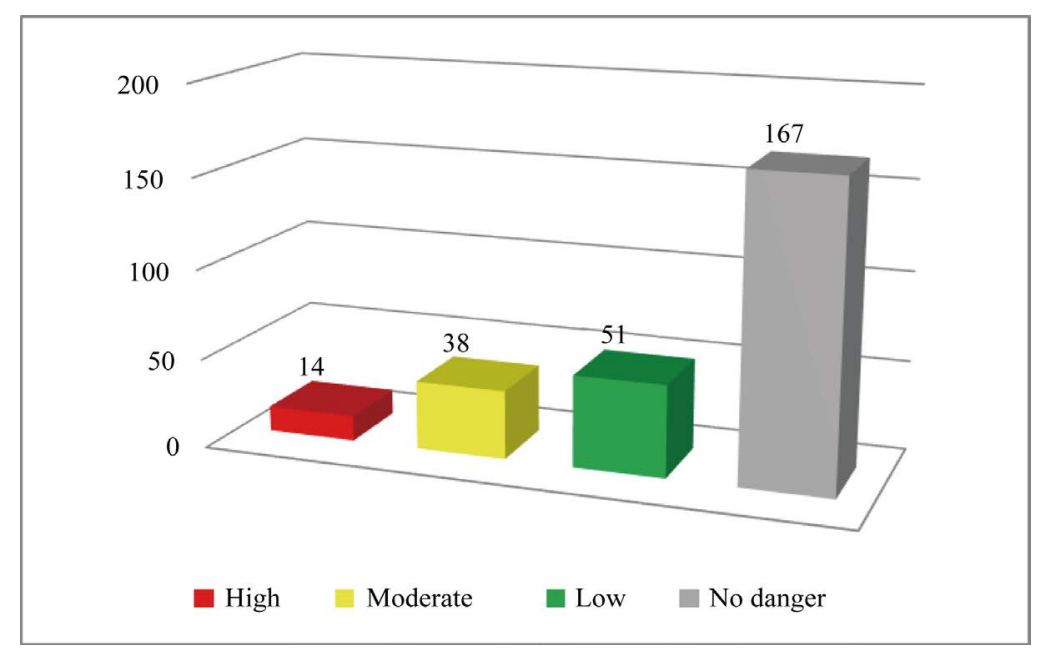

Figure 4. Number of settlements under Geological Hazard risk.

Village Didi Mitarbi. Landslide developed in the spring 2012 is in phase of temporary stability. It is sliding type, length is $120 \mathrm{~m}$, width in the tongue part $-60 \mathrm{~m}$, average width $-40 \mathrm{~m}$. Area is $4500 \mathrm{~m}^{2}$. Basis of this landslide are a homestead lands of local population at the foot of it. In previous year recommendation was issued for the purpose of process prevention which was not implemented. In case of activation 3 residential buildings at the foot of the slope will be endangered (Figure 10, Figure 11).

Township Bakuriani-for many years landslide body located at the foot of cable way leading to the mountain Kokhta, is stable. Tense situation is developed in the broad gully of TetriGhele, tributary of river Gujareti, where crushed stone-clayey flow formed, as a result of a break of broad gully closed by the landslide generated several years ago, and covered first floors of the residential buildings and auxiliary premises of 6 persons living in the Nikoladze street. Repeating of debris flow event in the broad gully is expected as many times as broad gully will be filled up and closed by the activated landslide. For the purpose of prevention it is necessary to periodically clean debris flow broad gully and narrow part of Nikoladze street [3] [4].

Debris flow broad gully of river Naghvarevi's water-in August 2008, as a result of Russian aggression, fire occurred on the territory of Borjomi municipality which damaged and completely destroyed woodland area up to 1000 ha. Intense erosion of slopes began. On the both slopes of broad gully landslide processes were developed. Almost all dry erosion broad gullies and ravines are able to form mudflows. On the bed of broad gully huge amount of terrigenous materials is accumulated (Figure 12) which is creating a danger to the population of village Daba. For the purpose of protection from debris flow/mudflows it is of urgent necessity to clear the bed of Naghvarevi broad gully so that in the period of next mudflows' proceeding which will inevitably happen village population should be protected from expected catastrophes. 


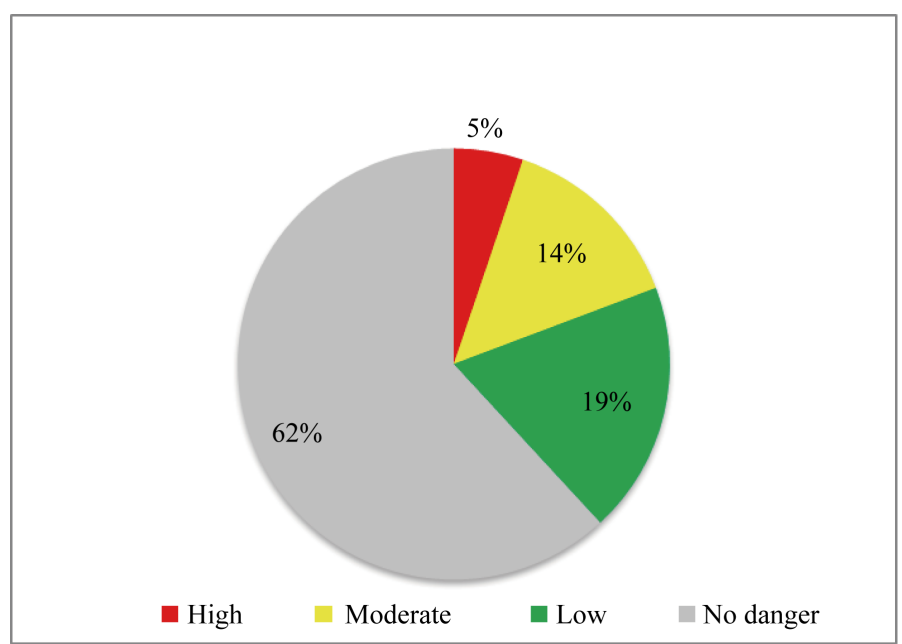

Figure 5. Number of settlements (percentage) under Geological Hazard risk.

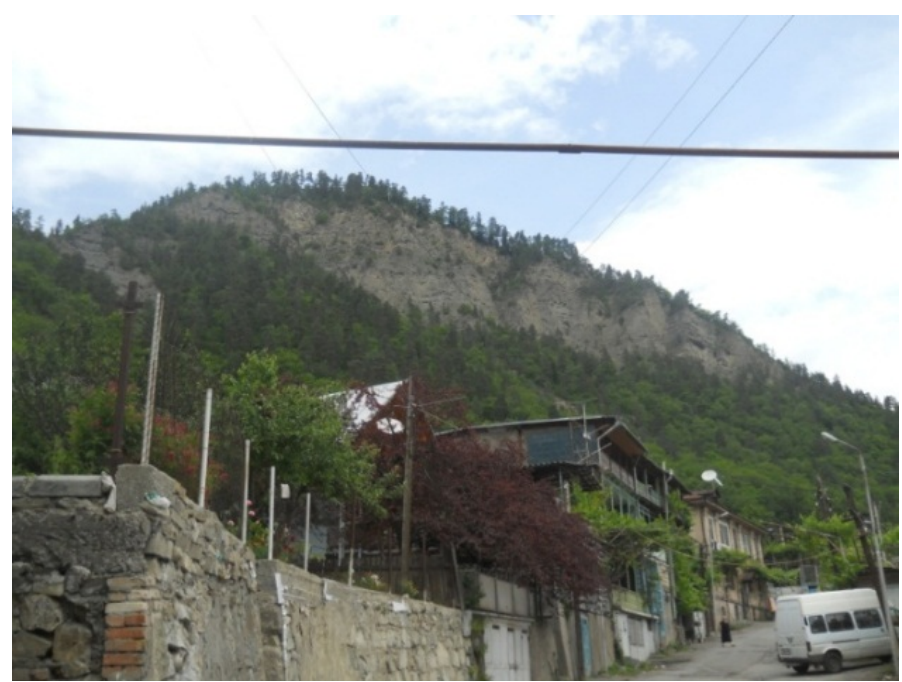

Figure 6. City Borjomi, rockfall area.

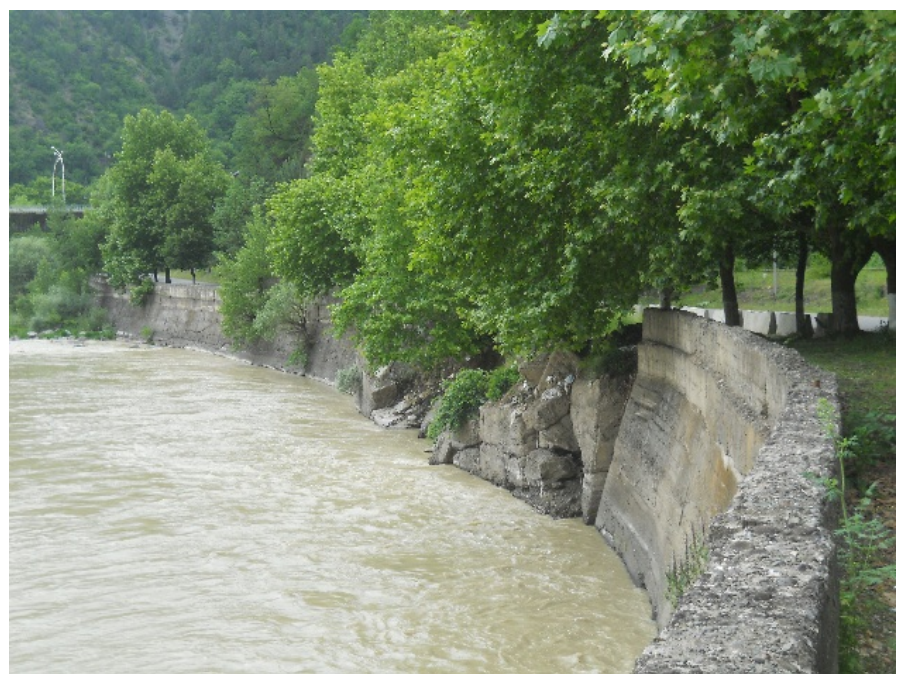

Figure 7. Riv. Mtkvari right bank erosion. 


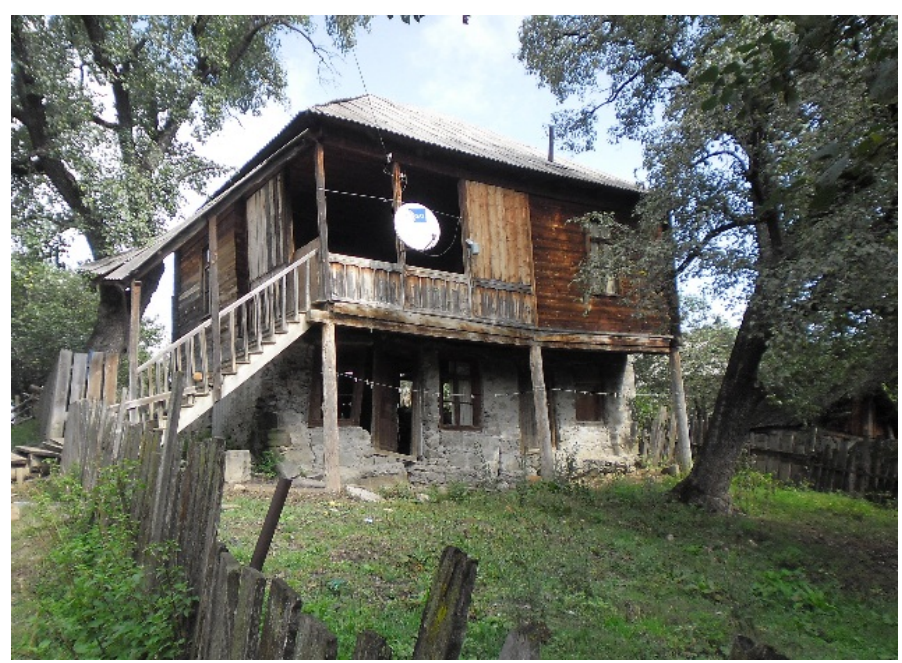

Figure 8. Village Dgvari, house damaged by landslide.

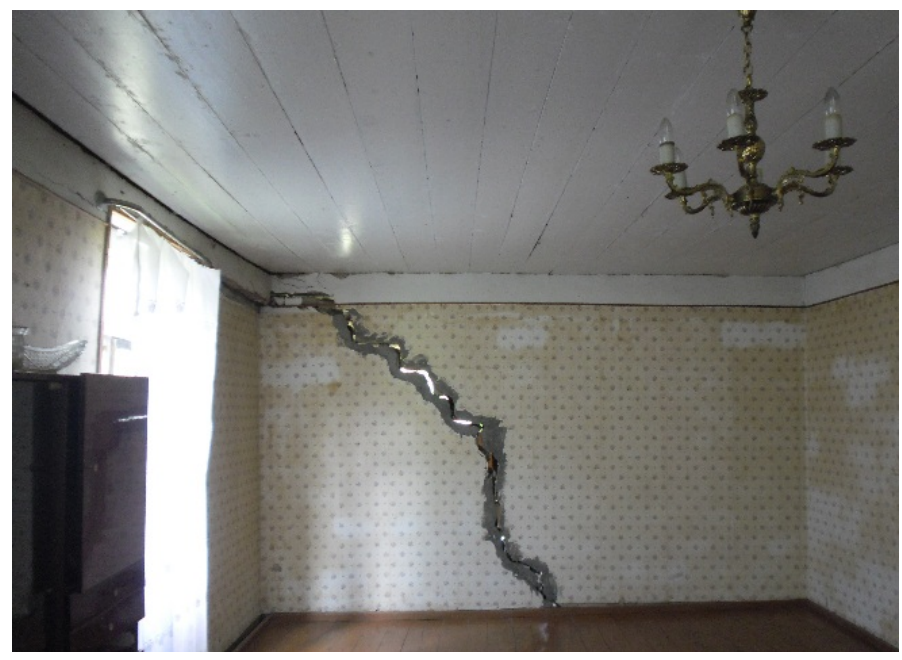

Figure 9. Village Dgvari, house damaged by landslide.

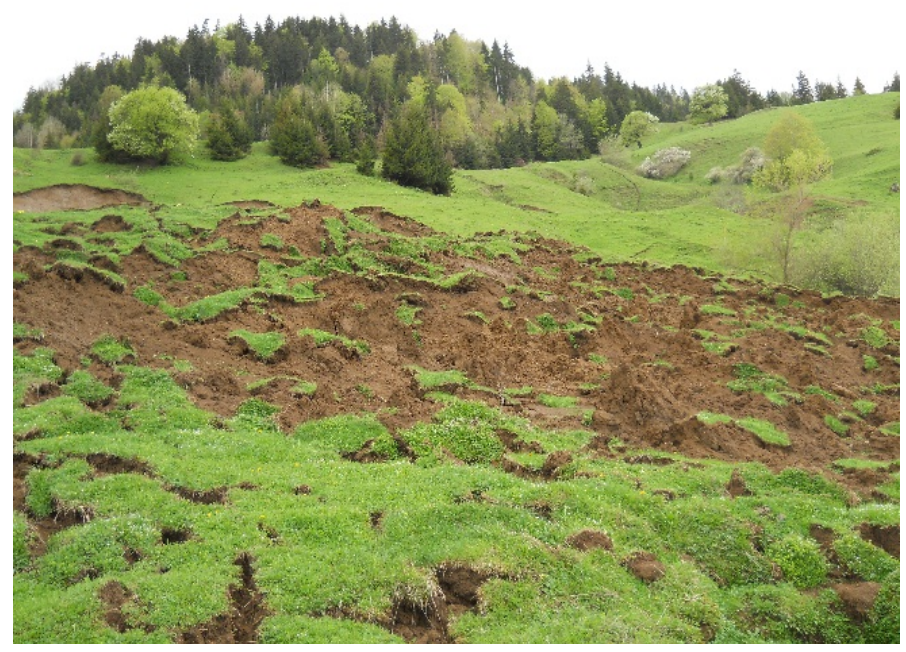

Figure 10. Village Didi Mitarbi landslide. 


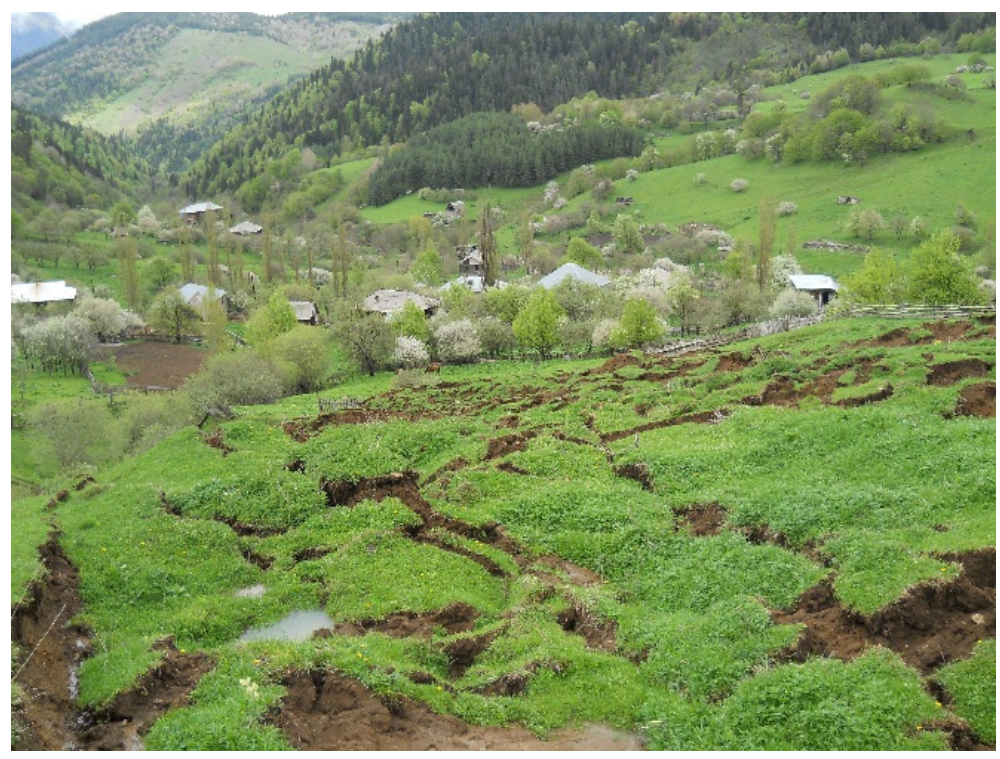

Figure 11. Village Didi Mitarbi landslide.

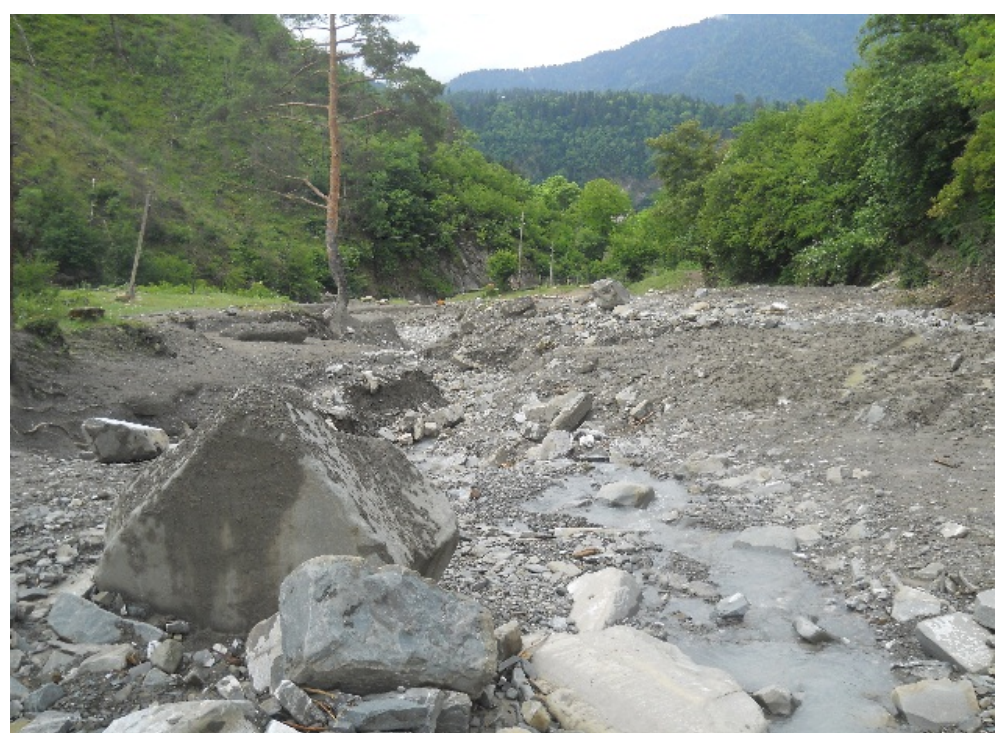

Figure 12. Naghvarevis Tskali debris flow.

In the village Sakire, in current year, during a spring flood river Sakirula eroded right bank on the length of 15 $\mathrm{m}$ which created a danger to the road. For the purpose of prevention, coast-protecting construction should be arranged.

On the road between villages Sakire and Dviri, in the spring of 2014, during a flood, river Sakirula damaged roadway in 5 sites and created danger to its functioning (Figure 13).

On the 19th kilometer of Borjomi-Bakuriani road landslide is still active which developed in 2008, on the right bank of river Borjomula. Its area is 0.2 ha. This landslide $2-3$ times a year damages the section of road with the length of $20 \mathrm{~m}$ and width of $5 \mathrm{~m}$. The amplitude of road-bed sag is about $30 \mathrm{~cm}$. For the purpose of prevention it is necessary to arrange coast-protecting constructions.

On this section the landslide which has an area of 1.9 ha, is periodically damaging the section of roadway with the length of $125 \mathrm{~m}$ and endangers cemetery located above the road. For the purpose of prevention it is necessary to regulate surface waters and carry out forestation of the slope. On the same road rockfall site is fixed which temporarily closed roadway (Figure 14). 


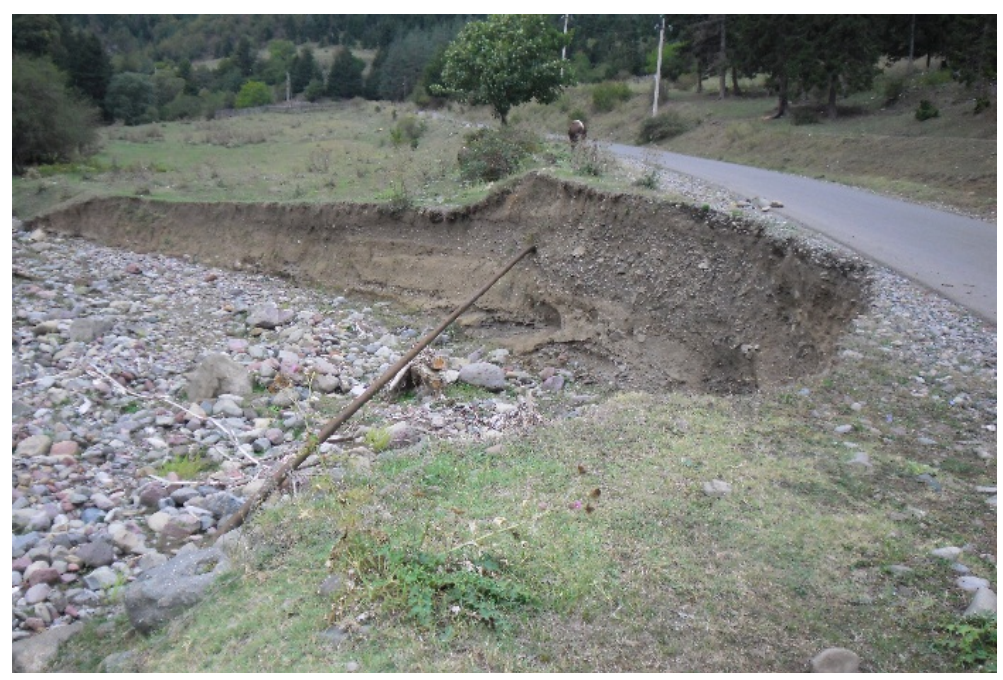

Figure 13. Sakire-Dviri damaged road.

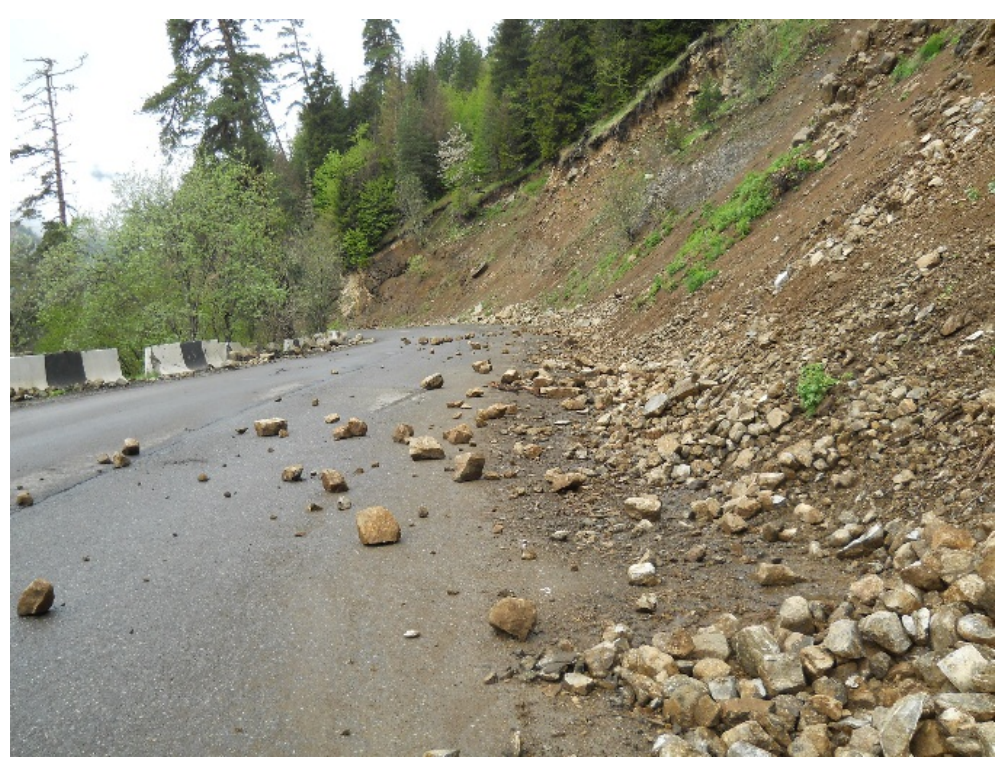

Figure 14. Rockfall (Borjomi-Bakuriani road).

On the territory of Borjomi municipality, in rivers' valleys, it is necessary to carry out cleaning works in Borjomi city, particularly in so called "Basein settlement" and in the valley of Dabis Tskali. Near the village of Timotesubani, on the right bank of Mtkvari, sustaining walls should be constructed in the streets of Jorjadze, 300 Aragveli and Plateau rise.

\section{Akhaltsikhe Municipality}

Village Gaghma Atskuri-landslide developed near the Atskhuri castle is still active (area-17.5 ha). This block type landslide developed during the earthquake of May 7, 2012. The length of landslide is $300 \mathrm{~m}$, average width—up to $100 \mathrm{~m}$, expected thickness- 5 - $6 \mathrm{~m}$. In the village 9 residential buildings are ruined, 12 households are under the high risk (Figure 15, Figure 16) [3] [4].

Village Thiseli-Landslide developed on the territory of this village is periodically active. Its area is 11.0 ha. This landslide during various occasions damaged 16 residential buildings, 7 buildings require repair which conditions might be worsened. In the Tkemlana-Sakuneti section on the bank of river Mtkvari is still alarming situation where intense erosion of bank is occurring on the length of $850 \mathrm{~m}$ (Figure 17) as a result of which vertical 


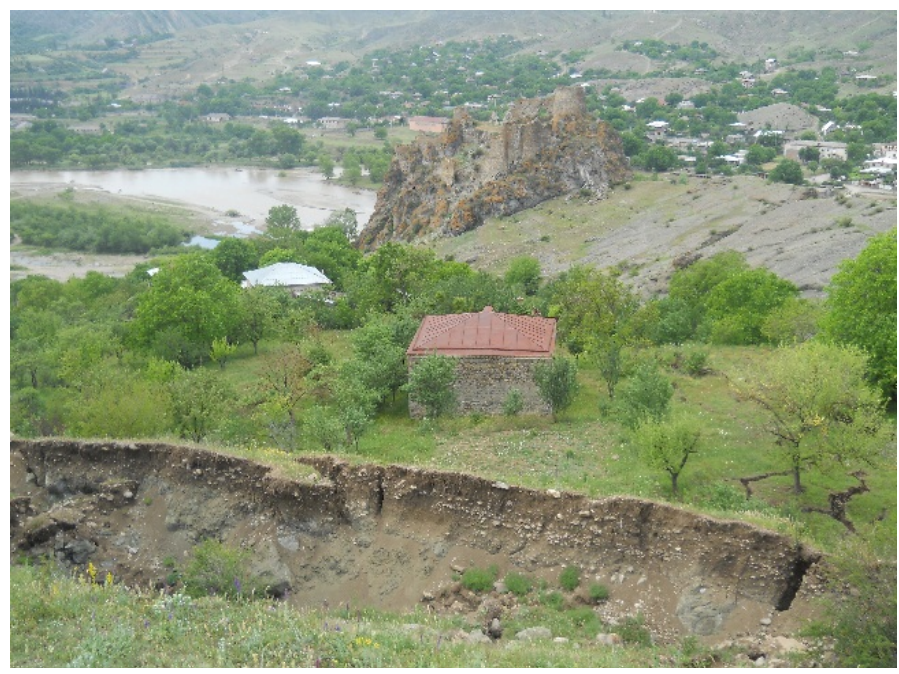

Figure 15. Village Gaghma-Atskuri landslide.

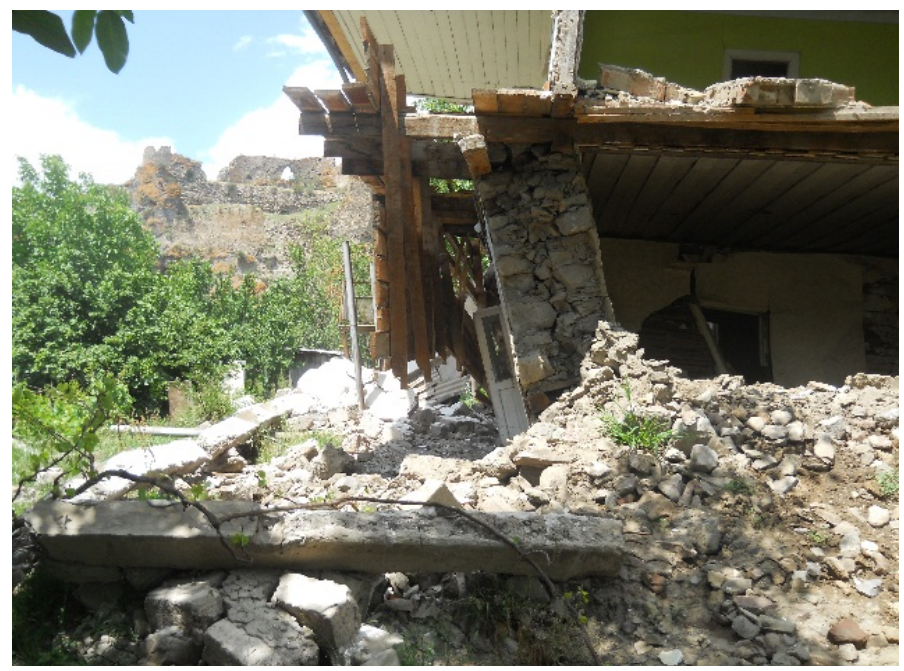

Figure 16. Village Gaghma-Atskuri landslide, destroyed house.

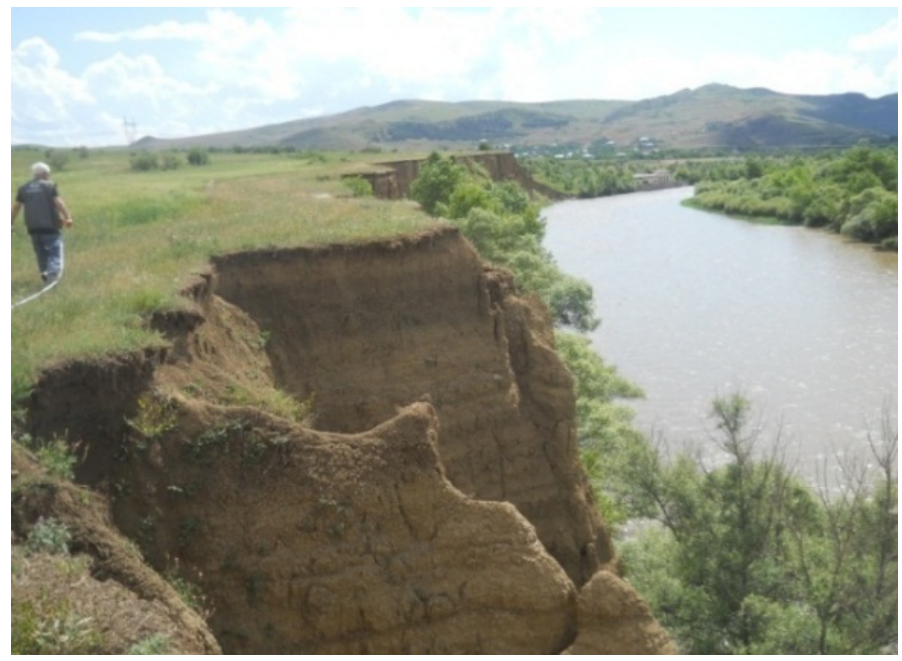

Figure 17. Riverbank erosion (Tkemlana-Sakuneti section). 
cliff of 15 - $18 \mathrm{~m}$ height is developed, and agricultural lands are eroded. For the purpose of prevention it is necessary to carry out coast-protecting works.

In the Akhaltsihke city, on the right bank of river Fotskhovi, ahead of $\mathrm{CO}_{2}$ producing plant, bank of river Mtkvari is eroded. In this site coast-protecting works were performed early but process is still going on. For the purpose of prevention it is necessary to arrange capital coast-protecting constructions.

Near the village Chobiskhevi, in the spring of 2014, debris fall from the slope for several hours completely closed road on the length of $35 \mathrm{~m}$ (Figure 18).

\section{Adigeni Municipality}

Village Ude. Two landslide sites are periodically active in this village, in the "Pirdapirebi" locality. Landslides developed on the slope with old erosion-landslide processes, having northern-eastern exposition. On the site I landslide length is up to $800 \mathrm{~m}$, area $-15.2 \mathrm{ha}$. The landslide at various times damaged up to 130 residential buildings, 6 buildings was completely destroyed, including local hospital. The landslide site is situated in the lower part of the slope. Its length is $350 \mathrm{~m}$ and width-160 m. Area is 4.0 ha. The basis of landslide is a flat, waterlogged territory. The landslide is active and modern. Its type is from slide to flow. It creates a danger to 2 residential buildings along the road passing in the upper part of the landslide [5].

The reason for both landslides' creation is a geo-morphological, geological and hydrogeological condition of the slope, overwetting of ground by atmospheric precipitation and economic activities of the population.

For the purpose of landslide processes prevention it is necessary to systematically fill up fractures, perform ramming, regulation of surface waters, restriction of irrigation of homestead lands and forestation of vacant territories.

In the village Ude, one 2-floor residential building is separated from the road with sustaining wall of $2.5 \mathrm{~m}$ height whose $8 \mathrm{~m}$ section is now falling apart because of low quality. Water is pouring in the yard during rains and causes dampening of walls. For the purpose of prevention it is necessary to restore damaged wall.

Village varkhani. Here regressive landslide developed on the right slope of river Otskhe is active. Its length along with valley is $130 \mathrm{~m}$, width-from 80 to $120 \mathrm{~m}$. On the slope early and newly created blocks are dumped (Figure 19) [6].

Village Abastumani. The landslide developed in the spring of 2011, on the middle part of slope, located to the north-east of village, is still active. It damaged water collector of Benara Kurtskhana aqueduct constructed in 1971 after which 9 villages were left without water supply. The length of landslide is $300 \mathrm{~m}$, average width$160 \mathrm{~m}$. The development of this landslide was caused by water leaking from the damaged pipes coming out from collector basin. The conclusion about urgent preventive works was sent to the governance of municipality which was not implemented. Currently pipes are placed on the surface of landslide. For stopping of active landslide it is necessary to fill up and ram all fractures on its surface, regulate surface waters, perform forestation of the slope.

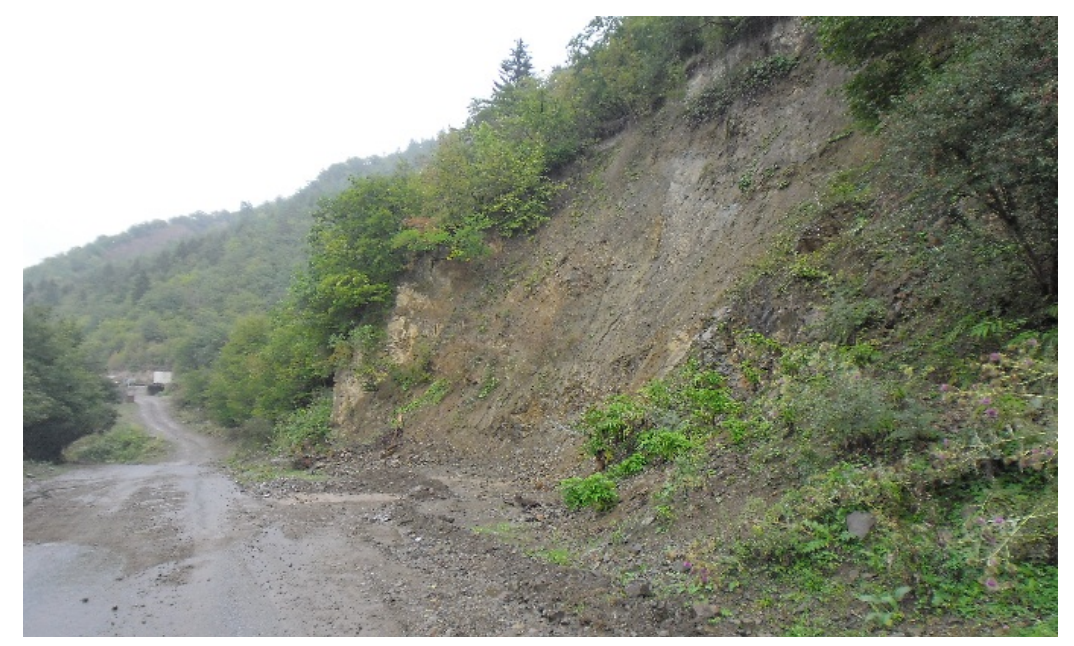

Figure 18. Rockfall (Chobiskhevi road). 


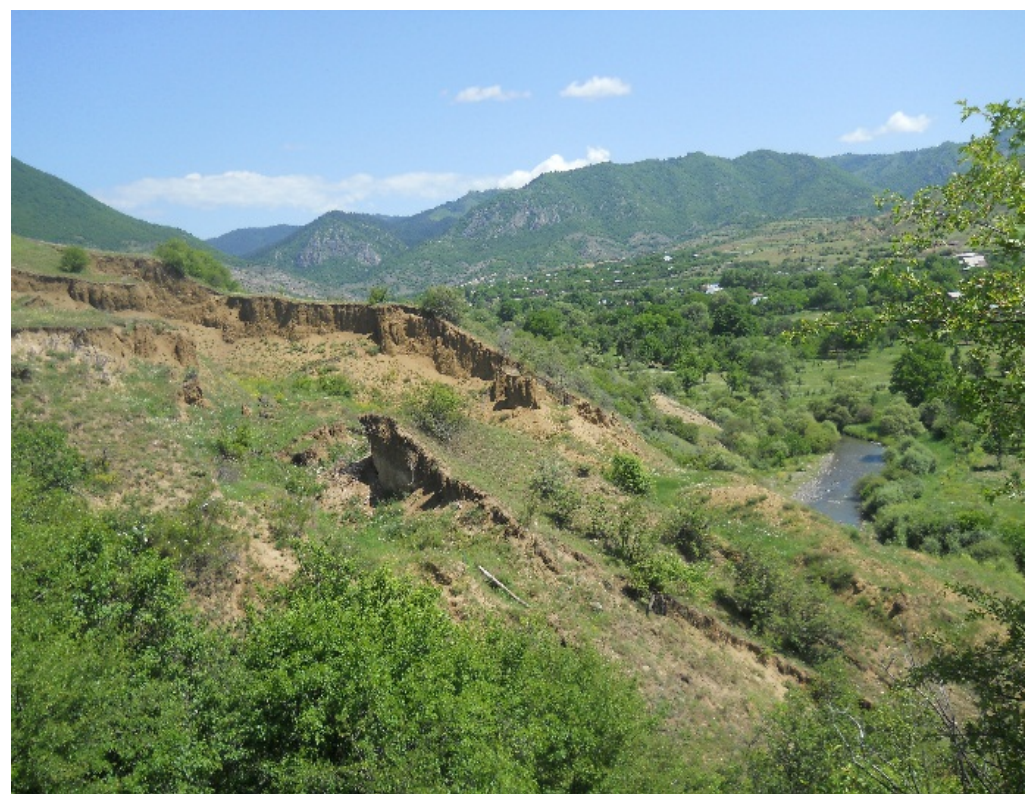

Figure 19. Varkhani landslide.

Village Arali. It is built on the right slope of river Kvabliani, having up to 150 inclination of northern exposition. Oligocene sandstones and gypsum loams compose its geological structure. These sediments are covered with eluvial-diluvial clays and loams of 2 - 3 m thickness which are unstable against erosion and landslide processes. The slope is completely old-landslide, stable, except certain parts. In the village one building is seriously deformed and damaged, dangerous for habitation.

Geological structures of villages Kharjami, Enteli, Bolajuri and Tsakhanistskaro are composed by Oligocene (P3) sandstones and gypsum clays which are covered with eluvial-diluvial clays and loams of 2 - $3 \mathrm{~m}$ thickness characterized by low hardness and bearing features.

In the village Kharjami 2-storey building staying along with the road initially was damaged during earthquake of 2007 year.

In the village Enteli buildings of two residents should be disassembled and newly built.

Village Tsakhanistskaro. The landslide developed at the foot of slope, having $10-200$ inclination of western exposition on the left bank of river Karkhulo, is periodically active. Its length is $200 \mathrm{~m}$, width—150 m, area3.0 ha. Its basis is a river bed. The landslide makes a danger to 3 residential buildings from which one is dangerous for habitation. In the same village, on the right bank of river, at the foot of slope of 10 - 120 inclination, 2 -storey residential home is built which is dangerous for habitation. The building should be disassembled and newly built.

\section{Aspindza Municipality}

Township Aspindza. On the landslide developed in 1989 on the Erekle II street it is stable situation. Here landslide body was developed on the slope of up to 200 inclination, with the length of $120 \mathrm{~m}$ and width of $25 \mathrm{~m}$. Its area is 0.4 ha, expected thickness $-2-3 \mathrm{~m}$. The landslide is pressing two residential buildings on the level of roofs. Residents of those buildings despite warnings do not want to relocate.

This landslide earlier already destroyed two buildings. There were several attempts to dispose earthen mass pushing on the buildings. But ground disposal was causing activation of landslide and impact on the buildings was repeated. We at different times issued conclusions where anti-landslide measures were indicated which weren't implemented. Ground disposal should be carried out not in a zone of contact with building but from top downward.

In township Aspindza, the landslide is periodically active which developed in 1985, on the upper part of the slope, at the prolongation of Erekle II street, adjacent to the "Aspindza castle". Its length is $300 \mathrm{~m}$, width—200 $\mathrm{m}$, area -6.0 ha. Its expected thickness is $2-3 \mathrm{~m}$. This landslide at different times destroyed 2 and damaged 6 
residential buildings. The landslide is under monitoring surveillance.

At the entrance of township Aspindza, shallow river known under the name of Otaskhevi, during the 1-hour high waters in the spring flooded central motorway, destroyed gabion under the road bridge, and also on the right bank of river damaged the section of local road at two sites, respectively on 25 - $30 \mathrm{~m}$ length. In these sites coast-protecting works should be done.

Village Nakalakevi. Certain sites of landslide developed on the right bank of river Mtkvari are still active in this village. The length of this complex type landslide is $2.5 \mathrm{~km}$, width from $0.5 \mathrm{~km}$ to $1.0 \mathrm{~km}$. Its area is $200 \mathrm{ha}$, and thickness-several tens of meters. 7 buildings are dangerous for habitation in the village to which another building was added in current year located at the lower part of landslide. Its dweller was relocated to the geologically safe place. The object is under monitoring surveillance [5].

Village Atskhvita. Here the landslide is active which developed on the left bank of river Mtkvari. Its length is up to $4 \mathrm{~km}$, width-from 150 - $200 \mathrm{~m}$ to $0.8-1.0 \mathrm{~km}$. Area is 320 ha, thickness—up to $10 \mathrm{~m}$. In the village 11 buildings were examined damaged by landslide process from which one is very dangerous for habitation. Its resident should be relocated to the geologically stable place. The landslide is under periodical monitoring surveillance.

Village Kuntsa. The landslide developed in the village adjacent to the village Atskhvita is in stable phase. The length is $1.5-1.6 \mathrm{~km}$, width in the tongue part reaches $1.0 \mathrm{~km}$. Its area is 160 ha, thickness-15 m. In the village 5 residential buildings are fixed damaged by landslide processes. From these buildings one is dangerous for habitation. Its resident should be relocated to the geologically stable place. The landslide is under periodical monitoring surveillance.

Village Zveli. In this village 4 damaged buildings were examined from which one is dangerous for habitation. Its resident should be relocated to the geologically stable place, and one building should be disassembled and newly built.

Akhaltsikhe-Aspindza motorway. The reconstructed road is following a basis of the left slope of river Mtkvari. This slope is geologically built by Eocene clays, sandstones, conglomerates, volcanic rocks-mainly basalts. These rocks are covered by eluvial-diluvial-colluvial formations which have a thickness in the range of $5-100$ $\mathrm{m}$. In the process of monitoring two sections of respective length of 50 and $20 \mathrm{~m}$ were discovered which were damaged by geological processes.

Rock massif situated on the territory of Vardzia monastery complex is a left slope of canyon-like valley of river Mtkvari built by Mio-Pliocene tuffs, tuff breccias and lava cover. Its absolute height is $1200-1600 \mathrm{~m}$. Vardzia rock massif is an active gravitational zone, rockfalls developed here are creating danger to the communications of monastery complex (cells cut in the cliff, tourist paths, car parking, etc.). For the complex which is cut in the cliff and other communications, upper horizon of main cliff (on façade side) is especially dangerous where, because of structural-textural peculiarities of volcanogenic rocks, blocks and clod are forming, having potential of gravitational movement (Figure 20, Figure 21). It is necessary to repair damaged parts of concrete trench located at the brow of cliff, adjacent to the rubble-concrete wall, also collect waters flew down from the slope above the gravitational cliff, and transfer them via the pipes to the base of slope, in the floodplain of river Mtkvari.

\section{Conclusions and Recommendations}

- The region consists of 6 municipalities, its total area is $6412.9 \mathrm{~km}^{2}$. There are 270 settlements in the region, and population, according to 2002 census, is 207698.

- Formation of Samtskhe-Javakheti region started at the end of Oligocene when, as a result of neo-tectonic movements and volcanic events plateau areas of Lesser Caucasus and southern Georgia were created which, in their turn, are divided on several districts and sub-regions, according to their genesis;

- Natural Hazards such as landslides, debris flow/mudflows, erosion, rockfalls, floods, weathering, are widespread in study area;

- 103 settlements (38\%) are under hazard risk zone;

- Geological hazard map was created on the result of field works and processing the historical information;

- Regulargeological monitoring is needed to assess the hazard, give recommendation to the local municipalities and population to avoid disaster by different type of natural hazards (Landslide, Debris flow, rockfall, erosion etc.). 


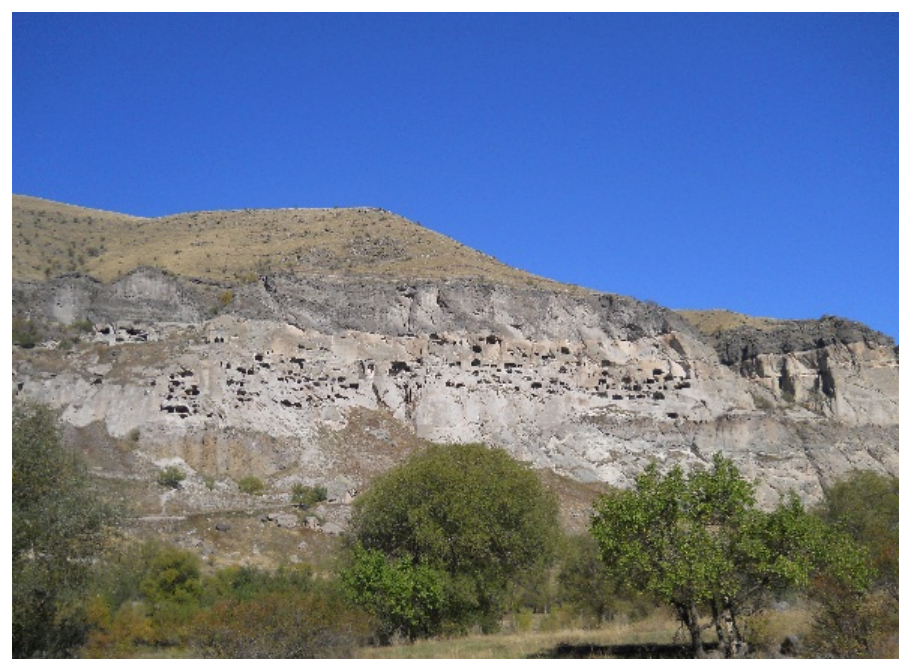

Figure 20. Vardzia monastery complex (general view).

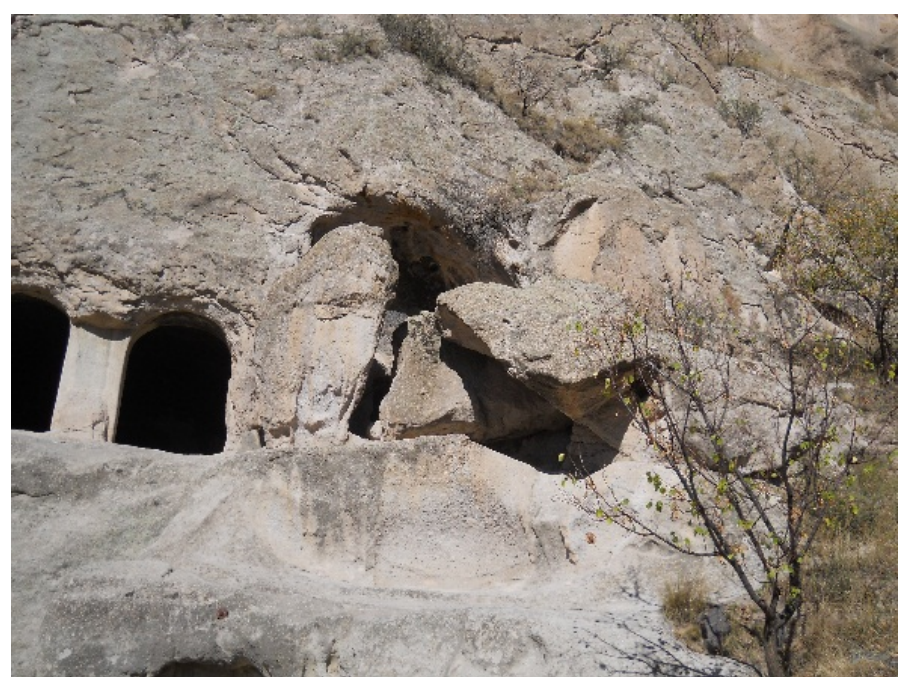

Figure 21. Rockfall processes in Vardzia complex.

\section{Acknowledgements}

The authors would like to thank National Environmental Agency of Ministry of Environment and Natural Resources Protection of Georgia for providing various datasets used in this study.

\section{References}

[1] Gobejishvili, R. (2011) Relief of Georgia. Ivane Javakhishvili Tbilisi State University, “Universal”, Tbilisi.

[2] Maruashvili, L. (1971) Geomorphology of Georgia, “Metsniereba”, Tbilisi.

[3] Informational Bulletin: Condition of Development of Geological Processes in Georgia, Results of Activation in 2014 and Danger of Risk by 2015-Summarizing Geological Report, Tbilisi, 2015.

[4] Informational Bulletin: Condition of Development of Geological Processes in Georgia, Results of Activation in 2013 and Danger of Risk by 2014—Summarizing Geological Report, Tbilisi, 2014.

[5] Informational Bulletin: Condition of Development of Geological Processes in Georgia, Results of Activation in 2010 and Danger of Risk by 2011—Summarizing Geological Report, Tbilisi, 2011.

[6] Tsereteli, Em., Gobejishvili, R., Tsereteli, N. and Gaprindashvili, M. (2008) Akhaltsikhe Depression Landslides and Formation of Arkhani Landslide in 2008. Collected Papers Vakhushti Bagationi Institute of Geography, New Series, 28-33. 